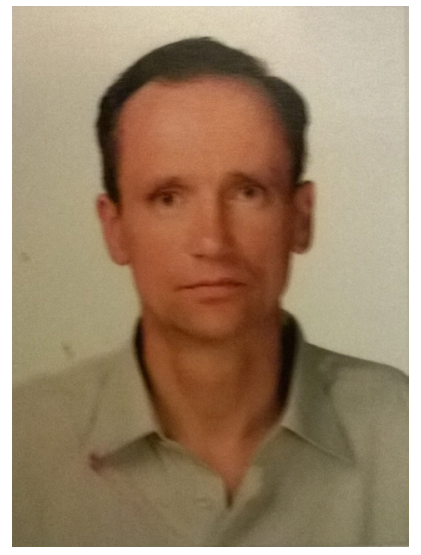

\section{Борис Савчук,}

доктор історичних наук, професор кафедри педагогіки та педагогічного менеджменту імені Богдана Ступарика,

ДВНЗ «Прикарпатський національний університет імені Василя Стефаника»

(м. Івано-Франківськ, Україна)

\section{Borys Savchuk,}

Doctor of History, Professor Department of Pedagogy and Pedagogical Management named after Bogdan Stuparik, Vasyl Stefanyk Precarpathian National University (Ivano-Frankivsk, Ukraine) borissavchuk@ukr.net ORCID ID 0000-0003-2256-0845

\section{Галина Білавич,}

доктор педагогічних наук, професор кафедри педагогіки початкової освіти, ДВНЗ «Прикарпатський національний університет імені Василя Стефаника»

(м. Івано-Франківськ, Україна)

\section{Halyna Bilavych,}

Doctor of Pedagogical Sciences, Professor of Department of Pedagogy of Primary Education, Vasyl Stefanyk Precarpathian National University (Ivano-Frankivsk, Ukraine)

ifosuhcvas@gmail.com

ORCID ID 0000-0002-1555-0932

\section{Юлія Душенко,}

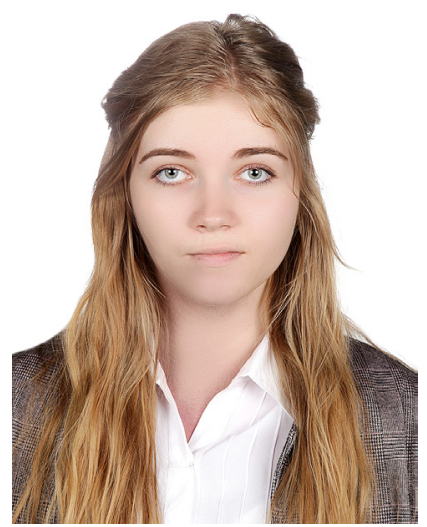

ДВНЗ «Прикарпатський національний університет імені Василя Стефаника»

(м. Івано-Франківськ, Україна)

\section{Yulia Dushenko,}

Student, Vasyl Stefanyk Precarpathian National University (Ivano-Frankivsk, Ukraine) andronika2000@gmail.com

ORCID ID 0000-0002-3196-9768

удк 378.147.

\title{
КОУЧИНГ ЯК ФІЛОСОФІЯ І ТЕХНОЛОГІЯ РОЗВИТКУ ПРОФЕСІЙНОЇ ПЕДАГОГІЧНОЇ ОСВІТИ
}

Анотація. У статті здійснено структуроване дослідження ідеологічних засад та методик і технік коучингу в контексті їхнього лояльного і ефективного використання в організації освітнього процесу педагогічного університету та професійної підготовки майбутніх учителів. З'ясовано етимологію поняття «коучинг», його різновиди та особливості освітнього коучингу. У контексті розвитку вищої школи та вдосконалення професійної педагогічної освіти розглянуто 
і предметно схарактеризовано коучинг у чотирьох взаємопов'язаних аспектах: 1) парадигми суб'єкт-суб'єктних діалогових стосунків у діаді «студент - викладач» (принципи партнерства усвідомленої відповідальності, віри в людину, ієрархічності розвитку, гнучкості, холізму); 2) коучингової компетентності як складника професійної компетентності; 3) коучингової технології (методики і техніки GROW, SMART, «м'яких» навичок; трьох вимірів - «3D» та ін.); 4) портфоліо досягнень. Коучинг як своєрідна міждисциплінарна багатовимірна філософія і технологія формування і розвитку особистості довів свою ефективність у різних галузях суспільного життя. Тож філософія і технологія коучингу мають значні потенційні можливості у формуванні компетентного і конкурентоздатного педагога.

Ключові слова: коучинг, освітній коучинг, вища школа, професійна підготовка майбутніх учителів, суб'єкт-суб'єктні стосунки..

\title{
COACHING AS PHILOSOPHY AND TECHNOLOGY OF DEVELOPMENT PROFESSIONAL PEDAGOGICAL EDUCATION
}

\begin{abstract}
The article deals with a structured researches of ideological principles and methods and techniques of coaching in the context of their loyal and effective use in the organization of educational process of the pedagogical university and vocational training of future teachers. The etymology of the concept «coaching" its variants and features of educational coaching. In the context of higher education development and improvement of professional pedagogical education, coaching has been considered and characterized in four interrelated aspects: 1) the subject-subject dialogue paradigms in the studentteacher dyad (conscious principles of partnership, conscious awareness), hierarchy of development, flexibility, holism); 2) coaching competence as a component of professional competence; 3) coaching technology (GROW, SMART techniques and techniques, soft skills; three dimensions - 3D, etc.); 4) portfolio of achievements.

Coaching as a kind of multidisciplinary multidimensional philosophy and technology of personality formation and development has proven effective in various areas of public life. Applying of coaching as a factor and tool for the development of higher education and improvement of professional pedagogical education is manifested in interrelated aspects concerning the paradigm of subject-subject dialog relations in the student-teacher dyad, formation of participants in the educational process of coaching, applying of coaching methods and techniques for the personal and professional growth of the educational acquirer and the portfolio of achievements for the reflection and self-reflection of successes and failures in the path of self-development. Therefore, coaching philosophy and technology have significant potential in forming a competent and competitive educator.
\end{abstract}

Keywords: coaching, educational coaching, the higher school, vocational training of future teachers, subject-subject relations.

\section{ВСТУП}

Постановка проблеми. Феномен коучингу - складний і багатогранний, має свою історію та застосовується в різних сферах суспільного життя. Його ідеологія і технологія дають значні потенційні можливості для розвитку професійної педагогічної освіти та потребують осмислення в проекції входження України в європейський освітній простір, переходу до практичної реалізації стандартів, актуалізованих Болонським процесом, зростання суспільних вимог до професійної підготовки вчителя. За таких умов науково-педагогічний працівник ЗВО має активно адаптувати інноваційні ідеї і технології в освітній процес вищої школи, реалізуючи запит на формування творчого, відповідального педагога, здатного обирати власну траєкторію навчання та долати перешкоди на шляху саморозвитку.

Аналіз останніх досліджень і публікацій. Основоположні філософські і практично-технологічні засади коучингу в галузях спорту, менеджменту, бізнесу, психології розробили його провідні теоретики М. Аткінсон, Т. Голвей, М. Дауні, К. Дуглас, С. Кові, Л. Уитворт, Дж. Уітмор, Е. Тач та ін. Підходи і можливості використання коучингу в різних ланках системи освіти, зокрема в освітньому процесі вищої школи, знайшли відображення у працях українських і зарубіжних учених-педагогів О. Баранової, Т. Борової, О. Відлацької, І. Голіяд, Н. Горук, В. Гульчевської, О. Нежинської, С. Романової, О. Соколової, В. Тименко, Т. Чернової, О. Шевчук та ін. Однак недостатня системність наукових рецепцій, з одного боку, та значні потенційні можливості продуктивного використання ідейних принципів, методик і технік коучингу у вищій школі, з іншого, актуалізують потребу поглибленого предметного з'ясування означеної в назві статті проблеми.

META I ЗАВДАННЯ ДОСЛІДЖЕННЯ полягають у структурованому дослідженні ідеологічних засад та методик і технік коучингу в контексті їхньої лояльного і ефективного використання в організації освітнього процесу педагогічного університету та професійної підготовки майбутніх учителів.

\section{РЕЗУЛЬТАТИ ДОСЛІДЖЕННЯ}

Етимологію слова «коуч» пов'язують із угорським містечком Коч, яке у XV ст. стало відомим завдяки виготовленню возів, екіпажів та карет, найкраща з них отримала назву «карета з Коч». Відтак семантика слова «коуч» розширилася, але при цьому передусім позначали те, що «допомагає швидко рухатися до мети». Короткий Оксфордський словник англійської мови дефінітив «соасһ» подає як дієслово у значеннях «тренувати», «вчити», «спрямовувати», «підказувати», «постачати фактами» (цит. за: Уитмор Дж., 2005, с. 16). У словникових виданнях та студіях зарубіжних і українських авторів (Аткинсон М., \& Рае Т. Чойс, 2009; Відлацька О., 2018; Голіяд І. С., \& Чернова Т. Ю., 2017; Голвей Т., 2005; Горук Н., 2015; Максимов В. Е., 2004; Парслоу Е., \& Рей М., 2003; Поберезька Г. Г., 2017; Романова С. М., 2010; Уитмор Дж., 2005) слово «коуч» - «соасһ» подається у значеннях «тренер», «наставник», а похідне від нього поняття «соасhing» переважно тлумачиться і вживається у значеннях «тренувати», «надихати», «наставляти», «консультувати» та ін. 
Ідейним фундатором коучингу став педагог-теоретик Гарвардського університету Т. Геллвей (Gallwey), який у книзі «Внутрішня гра в теніс» («The Inner Game of Tennis», 1974) і ще кількох бестселерах виклав його наріжні ідеї. Стрижневим стало поняття «внутрішній» для відображення стану гравця, який за підтримки наставника повинен знайти свій шлях для реалізації власних здібностей і досягнення результату. Революційність ідеї Т. Гелвея полягала в тому, що для розкриття потенціалу людини і підвищення її ефективності «коуч» (тренер) має «не вчити, а допомагати вчитися» (Голвей Т., 2005).

У 80-90-х рр. XX ст. коучинг з царини спорту «перекочував» у сфери бізнесу, менеджменту, управління й освіти. На початку XXI ст. фахівці налічують близько десяти його основних різновидів: коучинг лідерства (супровід і мотивація працівників); лайф-коучинг (планування життя, досягнення особистих цілей); професійний коучинг (охоплює процес від пошуку роботи до визначення цілей і планування шляхів кар'єрного зростання); адміністративний; бізнескоучинг; коучинг спорту; сімейний коучинг; коучинг особистої ефективності тощо (Максимов В. Е., 2004).

Основна особливість освітнього коучингу полягає в тому, що він найбільш органічно інтегрує інші різновиди цього феномену. Синтезуючи доробок різних авторів (Відлацька О., 2018; Голіяд І. С., \& Чернова Т. Ю., 2017; Горук Н., 2015; Максимов В. Е., 2004; Поберезька Г. Г., 2017; Романова С. М., 2010; Шевчук С.П., \& Шевчук О.С., 2016), визначаємо його як комплексний інструмент (ідея, метод, технологія, середовище) підвищення ефективності організації освітнього процесу у взаємодії взаємин «педагог - здобувач освіти», «педагог - педагог», «педагог адміністратор» тощо та в різних аспектах їхньої діяльності (мотивація, методика, моніторинг тощо).

У контексті розвитку вищої школи та вдосконалення професійної педагогічної освіти розглядаємо і предметно характеризуємо коучинг у чотирьох взаємопов'язаних аспектах: 1) парадигми суб'єкт-суб'єктних діалогових стосунків у діаді «студент - викладач»; 2) коучингової компетентності; 3) коучингової технології; 4) портфоліо досягнень.

Перший базовий аспект визначає зміст і характер реалізації всього потенціалу ідеології і технології коучингу у вищій школі. Він проектує поступальний перехід від традиційної системи аудиторного навчання, коли педагог виступає «носієм готових знань», до індивідуальної, проектної, тренінгової, дистанційної форм організації освітнього процесу, який переходить у площину рівноправної партнерської навчальної комунікації.

Синтезуючи широкий спектр рецепцій ідеологів коучингу (Аткинсон М., \& Рае Т. Чойс, 2009; Голвей Т., 2005; Парслоу Е., \& Рей М., 2003; Уитмор Дж., 2005) та його інтерпретаторів (Відлацька О., 2018; Голіяд І. С., \& Чернова Т. Ю., 2017; Горук Н., 2015; Максимов В. Е., 2004; Поберезька Г. Г., 2017; Романова С. М., 2010; Шевчук С.П., \& Шевчук О.С., 2016), визначаємо такі, з нашого погляду, основоположні принципи коучингової міжособистісної взаємодії: 1) партнерства - передбачає діалогічну комунікацію на рівноправній суб'єкт-суб'єктній основі зі збереженням і виконанням відповідних рольових функцій і обов'язків; 2) усвідомленої відповідальності і віри в людину - означає, що викладач має допомогти студентові зрозуміти, «чого насправді він хоче», «яким особистим потенціалом він володіє», та перебудувати стиль його мислення від намагання «уникнути невдачі» до мотивації «досягнення успіху», який залежить від нього самого, його саморозвитку; 3) ієрархічності розвитку та гнучкості - окреслюють і визначають поетапність формування і реалізації стратегій особистісного і професійного зростання; утверджують потребу чіткого розуміння «теперішнього» стану, необхідності змін та зосередження уваги на майбутньому; акцентують на потребі подолання стереотипів мислення, розвитку творчості і креативності, усвідомлення алгоритмів власної поведінки; 4) холізму - означає розуміння взаємозв'язку усіх сфер життєдіяльності особи, так що зміни (позитивні, негативні) в одній з них неодмінно й відповідно відбиваються на іншій.

Важлива особливість коучингової міжособистісної взаємодії у контексті нашого дослідження полягає в розумінні і правильному виконанні рольових функцій. Ідеться про те, що коуч-викладач відповідає за визначення і узмістовлення процесу просування до мети, а здобувач освіти - за досягнення результатів; коуч-педагог не дає «Готових рецептів», не нав'язує «правильних рішень», а фасилітує (допомагає, сприяє, полегшує), відстежує й за потреби корегує пошук студентом оптимальних шляхів і рішень, який розв'язує чергові завдання не з примусу, а 3 власної волі, свідомо, із задоволенням.

Ефективність використання філософії і технологій коучингової взаємодії у процесі професійної педагогічної підготовки великою мірою залежить від усвідомлення майбутніми вчителями, по-перше, різниці між тим, «чим вони € на старті» просування до мети, і тим, «чим/ким вони хочуть стати на фініші», та, по-друге, від їхньої готовність і здатності постійно рухатися вперед, долаючи чергові перешкоди на шляху до акме-успіху.

Другий аспект, що стосується коучингової компетентності в контексті досліджуваної проблеми, розглядаємо як складник професійної компетентності і науково-педагогічного працівника вишу, і здобувача освіти - майбутнього педагога. Синтез її фрагментарного розгляду в окремих тематичних студіях (Відлацька О., 2018, с. 23-26; Голіяд І. С., \& Чернова Т. Ю., 2017, с. 24-25) та всебічного представлення феномену професійної компетентності в сучасному науково-педагогічному дискурсі дозволяє стверджувати, що коучингова компетентність викладача і здобувача освіти передбачає набуття: а) коучингових знань, що акумулюють широкий спектр відомостей про ідеологію і технологію коучингу, та психофізіологічні особливості суб'єктів освітнього процесу; б) умінь і навичок налагодження ефективної комунікативної взаємодії, що можлива лише в атмосфері взаємної довіри, щирих і доброзичливих стосунків, поєднаних із вимогливістю, відповідальністю; в) особистісних якостей, які виявляються у творчості, ініціативності, емпатії, самодисципліні, відповідальності, жертовності; г) готовності особи до постійного самонавчання і саморозвитку як під час навчання у виші, так і в професійній діяльності.

Оволодіння коучинговою компетентністю як складника професійної обізнаності означає готовність і здатність педагога розробляти ефективні довгострокові програми формування і розвитку суб'єктів освітнього процесу; здійснювати добір ефективних інструментів і технік коучингу, що забезпечують швидкий і ефективних шлях 
досягнення результатів; мотивувати та «непомітно, але реально» супроводжувати самостійне просування учня, студента до досягнення поставлених цілей.

Розвиток коучингової компетентності педагога передбачає постійне розширення професійного простору (у його професійній і психологічній сферах), генерування нових ідей, переосмислення власних потенційних можливостей і можливостей здобувачів освіти, корегування обраних стратегій і тактик особистісного і професійного зростання, диверсифікацію інструментів їхньої реалізації.

Третій аспект, що стосується коучингової технології найбільше представлений у науково-педагогічний літературі та водночас $є$ найменш структурованим і розробленим у дефінітивному відношенні. Така ситуація об'єктивно зумовлена міждисциплінарним характером коучингу за джерелами походження і формування та його використанням у різних галузях суспільного життя. Тому коучингову технологію розглядають в одному синонімічному ряді як «систему технологій і методів», «коучинг-метод», «коучинг-техніку», «коучинговий підхід», «форму консультування», «вид менеджменту», «самоменеджмент» тощо. Означені види діяльності та операційні інструменти насправді мають спільну ідеологічні основу, що спрямовує на постановку і максимально швидке досягнення цілей, але відрізняються в сутнісному змістовно-технологічному сенсі, що може стати предметом окремого дослідження.

у структурі коучингової технології умовно виокремлюємо два нероздільно взаємопов'язані складники, які визначають етапність і орієнтири (1) та техніку і методику (2) міжособистісної комунікації в процесі організації і просування шляхом особистісного і професійного зростання. Вони виявляються в дефінітивно неврегульованих поняттях («коучинг-техніка», «коучинг-метод/методика», «коучинг-модель/моделювання» тощо) та цікаві й зручні у використанні, мають значний ресурсний потенціал, виразну формувальну спрямованість і досвід практичної апробації. Привабливості їм надають виразні назви, які цілісно структуруються за абревіатурним принципом формулювання.

У загальній спільній основі коучингові методи і техніки передбачають визначення мети і мотивацію на їі досягнення, усвідомлення реалій (особистісних ресурсів, можливих перешкод на обраному шляху тощо); планування дій; вибір, пошук і створення нових ресурсів (методи, форми, засоби, заходи просування за обраним шляхом); моніторинг результатів, саморефлексію (Аткинсон М., \& Рае Т. Чойс, 2009; Голвей Т., 2005; Парслоу Е., \& Рей М., 2003; Поберезька Г. Г., 2017; Романова С. М., 2010; Уитмор Дж., 2005; Шевчук С.П., \& Шевчук О.С., 2016). Розроблені й апробовані теоретиками і практиками коучингу у сферах спорту, бізнесу, менеджменту та ін. технології і методики в різних ракурсах адаптуються в освітній процес українських вишів.

Як приклад відзначмо розроблені або розвинуті Е. Парслоу і М. Рей техніки «структури навичок», «3-D» (трьох вимірів), методику GROW та ін. (Парслоу Е., \& Рей М., 2003, 75-87), які активно (і переважно без покликання на першоджерела) популяризуються в сучасній науково-педагогічній літературі. Так, в основі методики (техніки) GROW (анг. - зростання), яку першим запропонував Т. Геллвей (Голвей Т., 2005), а розвинув Дж. Уітмор (деталізував суть, механізми, послідовність, очікувану результативність, інші компоненти), лежить чотириступенева змістовнофункційна модель, що передбачає: 1) визначення цілей (анг. goal - мета) і завдань просування обраним шляхом; 2) з'ясування реального (англ. reality - реальність) стану проблеми та ресурсів, необхідних для її розв'язання; 3) пошук і вибір відповідних оптимальних/ефективних варіантів (англ. - option - варіант); 4) докладання волі (англ. will - воля) і зусиль для реалізації обраних стратегій та їхню перевірка в дії (Парслоу Е., \& Рей М., 2003, с. 81-82).

Головними засобами реалізації цієї техніки є постановка конкретних логічно пов'язаних запитань, які почергово ставляться перед особою на кожному з означених етапів коучингу. Зокрема: 1) «Чого ми хочемо?; яка наша мета?; чи є мета конкретною, вимірною?; у якому напрямі хочемо працювати?» та ін.; 2) «У якій ситуації перебуваємо?; якими ресурсами володіємо?; які перешкоди очікують?; які чинники можуть вплинути на ситуацію?; якими методами і засобами просуватися до мети?» та ін.; 3) «Чи правильно діємо?; чи потребують наші дії корекції?; що ще можна зробити для досягнення цілі?; які підходи (методи, засоби) до розв'язання конкретних завдань $€$ найбільш прийнятними?» тощо; 4) «Чи докладаємо належних/усіх зусиль для досягнення мети?; чи маємо сумнів у правильності обраного шляху?; чи впевнено долаємо перешкоди у своїй діяльності?» і т. ін. (Парслоу Е., \& Рей М., 2003, с. 81-82; Уитмор Дж., 2005, с. 47-89).

Популярними також є триступеневі коучингові техніки, що проектують просування обраним шляхом для досягнення конкретних особистісних та професійних, зокрема вузькопрофільних цілей. Так, ідентично орієнтовані методи SMART (specified - конкретний; measurable - вимірюваний, agreed - узгоджений, realistic - реалістичний, timed обмежений у часі) та SMAC (ті ж значення, окрім останнього, challenging - стимулюючий) слугують формуванню умінь ставити конкретні реальні цілі та досягати їх у визначений/обмежений час. Вплив означених та інших коучингових технік («структурна»; «спіраль практики»; «м'яких» навичок; трьох вимірів - «3D» тощо) на особисте і професійне життя вимірюється в конкретних показниках та формалізується в категоріях, що узгоджують і зіставляють теперішню ситуацію із життєвими планами (Е. Парслоу і М. Рей (Парслоу Е., \& Рей М., 2003, 75-83) та ін.).

У теорії і практиці сучасної педагогіки домінує тенденція щодо опису згаданих та інших «традиційних» методів коучингу та їхньої адаптації в освітній процес вищої школи (див., напр.: (Відлацька О., 2018; Горук Н., 2015; Парслоу Е., \& Рей М., 2003; Поберезька Г. Г., 2017; Романова С. М., 2010; Шевчук С.П., \& Шевчук О.С., 2016)). При цьому вони зазвичай виражаються в категоріях сучасної педагогіки та структуруються як технології педагогічного супроводу, що в акумульованому вигляді можна представити в таких етапах і їхньому змістовому наповненні: цілепокладання (визначення цілей); діагностично-прогнозувальний (фіксація і обговорення проблем з позиції здобувача освіти, мотивація на їхнє розв'язання), планувально-проектувальний (моделювання ситуацій, відповідальність за розв'язання проблем; діяльнісний (за опосередкованою допомогою коуча-викладача студент 
самостійно просувається обраним шляхом); рефлексивний (обговорення успіхів, помилок і їхніх причин, визначення перспектив подальшого розвитку).

Особливість і перевага коучингової технології педагогічного супроводу полягають у виразній особистісній, соціальній, професійній орієнтованості на здобувача освіти, який позитивно мотивується та почувається морально врівноваженим, упевненим, захищеним, та виявляє готовність до самореалізації свого потенціалу, адекватної самооцінки, подальшого саморозвитку.

Продуктивними і перспективними видаються розробки українських учених, які розглядають коучинг як метод і технологію вдосконалення освітнього процесу у вищій школі в контексті її реформування. Зокрема, С. Шевчук і О. Шевчук показали суголосність засад і технік освітнього коучингу та концепції «Освіта 3.0». У теоретичному аспекті це виявилося у двох групах принципів. Перша актуалізує принципи, зумовлені характером сучасної вищої школи: суб'єктивності - передбачає здійснення освітньої діяльності лише за навчальними програмами, укладеними у відриві від студента; надмірності - насиченості освітнього процесу різними джерелами знань; рівноправності ідеться про «викладача-лідера» на противагу «викладачеві-драйверу». У контексті розвитку мережевих технологій, як чинників і засобів удосконалення освітнього процесу у вишах, учені розкривають потенціал другої групи принципів (Торрера; Соціальної мережі; Твітгера; Блогу; Вікі; Пошуковика; Коментів), які передбачають різні методи, форми, засоби пошуку, обробки, обміну інформацією (Шевчук С.П., \& Шевчук О.С., 2016).

Так само продуктивною з позицій удосконалення теорії і практики організації освітнього процесу у вищій школі України виглядає інтерпретація Г. Поберезькою коучингу як педагогічної технології студентоцентричного навчання (Поберезька Г.Г., 2017).

Осмислення крізь призму наукового дискурсу (Романова С. М., 2010, с. 85-86; Шевчук С.П., \& Шевчук О.С., 2016, с. 62-63) сутності четвертого аспекту, що стосується коучингового портфоліо, у концентрованому вигляді можна представити як «здатність показати все, на що ти здатний». Його відмінність від упроваджуваних в освітній процес вищої школи моніторингових моделей полягає у зміщенні акцентів з того, що здобувач освіти «має/повинен» знати і вміти, на те, що він вже знає і вміє в конкретній сфері, яка варіюється від окремого навчального предмета до професійної компетентності, вираженої в здатності і готовності до виконання професійно-педагогічних обов'язків.

У ракурсі нашого дослідження коучингове портфоліо можна визначати як «портфель особистих досягнень», що визначає, яким чином і наскільки успішно здобувач освіти просувається власною траєкторією саморозвитку та набуває різні професійні компетентності. Коучингове портфоліо розглядаємо у вимірах педагога та здобувача освіти як їхню комунікативну цілісність. Це виявляється у з'ясуванні того, у якій мірі та як ефективно обидва суб'єкти освітнього процесу реалізують свої рольові функції та зусилля щодо підтримки, збереження і розвитку мотивації навчання; заохочення майбутнього вчителя до самостійності, з одного боку, та усвідомлення ним потреби розширювати свої можливості в навчанні і самонавчанні, з іншого; розвитку навичок рефлексивної оціночної та самооціночної діяльності; сформованості умінь ставити цілі та планувати й організовувати персональну діяльність; сприяння індивідуалізації навчання студента та його потенційної самореалізації; сприяння особистій соціалізації здобувача освіти та його свідомій, цілеспрямованій самосоціалізації.

Для реалізації коучингового портфоліо на практиці може бути доцільним і ефективним застосування методу взаємної оцінки. Він формує досвід рефлексії і саморефлексії, який дозволяє студентові неупереджено визначати результати власної праці та діяльності іншої особи, зокрема викладача, вчить визнавати власні помилки і успіхи, підвищує і стимулює готовність і здатність самостійно вибудовувати траєкторію власного життя, брати відповідальність за своє життя і життя країни.

\section{ВИСНОВКИ ТА ПЕРСПЕКТИВИ ПОДАЛЬШИХ ДОСЛІДЖЕНЬ}

Коучинг як своєрідна міждисциплінарна багатовимірна філософія і технологія формування і розвитку особистості довів свою ефективність у різних галузях суспільного життя. Застосування коучингу як чинника та інструмента розвитку вищої школи і вдосконалення професійної педагогічної освіти предметно виявляється у взаємопов'язаних аспектах, що стосуються парадигми суб'єкт-суб'єктних діалогових стосунків у діаді «студент - викладач», формування в учасників освітнього процесу коучингової компетентності, використання коучингових методів і технік для особистісного і професійного зростання здобувача освіти та портфоліо досягнень для рефлексії і саморефлексії успіхів і невдач на шляху саморозвитку. Тож філософія і технологія коучингу мають значні потенційні можливості у формуванні компетентного і конкурентоздатного педагога.

Актуалізуємо доцільність проведення комплексного дослідження коучингу як освітньо-педагогічного феномену для його цілісної структуризації та виявлення потенційних можливостей щодо розв'язання широкого спектру завдань професійної підготовки майбутніх фахівців.

\section{СПИСОК ВИКОРИСТАНИХ ДЖЕРЕЛ}

Аткинсон, М., \& Рае Т. Чойс. (2009). Пошаговая система: Наука и искусство коучинга / пер. с англ. Київ: Companion Group.

Відлацька, О. (2018). Педагогічний коучинг як технологія професійного розвитку керівника гуртка в системі позашкільної освіти: методичний посібник. Кам'янець-Подільський: Науково-методичний відділ ЏДЮТ.

Голвей, Т. (2005). Работа как внутренняя игра / пер. с англ. Москва: Альпина Бизнес Букс.

Голіяд, І. С., \& Чернова, Т. Ю. (2017). Роль коучингової компетентності педагога у розкритті потенціалу суб'єкта освітнього процесу. Наук. часоп. НПУ імені М. П. Драгоманова. Сер. 13. Проблеми трудової та професійної підготовки, 8, 20-25.

Горук, Н. (2015). Коучинг як ефективна технологія формування самоосвітньої компетентності студентів. Проблеми підготовки сучасного вчителя, 11, 99-105. 
Максимов, В. Е. (2004). Коучинг от А до Я. Возможно все. Санкт-Петербург: Речь.

Парслоу, Е., \& Рей, М. (2003). Коучинг в обучении. Практические методы и техники. Санкт-Петербург: Питер.

Поберезька, Г. Г. (2017). Коучинг як педагогічна технологія студентоцентричного навчання у ВНЗ. Технологія і техніка друкарства, 4, 99-107.

Романова, С. М. (2010). Коучинг як нова технологія в професійній освіті. Вісник Національного авіаційного університету. Сер. Педагогіка. Психологія, 3, 83-86.

Уитмор, Дж. (2005). Коучинг высокой эффективности. / пер. с англ. Москва: Международная академия корпоративного управления и бизнеса.

Шевчук, С.П., \& Шевчук, О.С. (2016). Коучинг як метод навчання студентів у контексті реформування вищої освіти України. Наук. праць. Чорномор. держ. у-ту ім. П. Могили. Сер.: Педагогіка, 269(257), 62-65.

\section{REFERENCES}

Atkynson, M., \& Rae T. Chois. (2009). Poshahovaia systema: Nauka i iskusstvo kouchynha / per. s anhl. Kyiv: Companion Group.

Vidlatska, O. (2018). Pedahohichnyi kouchynh yak tekhnolohiia profesiinoho rozvytku kerivnyka hurtka v systemi pozashkilnoi osvity: metodychnyi posibnyk. Kamianets-Podilskyi: Naukovo-metodychnyi viddil TsDluT.

Holvy, T. (2005). Rabota kak vnutrenniaia ihra / per. s anhl. Moskva: Alpyna Byznes Buks.

Holiiad, I. S., \& Chernova, T. Yu. (2017). Rol kouchynhovoi kompetentnosti pedahoha u rozkrytti potentsialu subiekta osvitnoho protsesu. Nauk. chasop. NPU imeni M. P. Drahomanova. Ser. 13. Problemy trudovoi ta profesiinoi pidhotovky, 8, 20-25.

Horuk, N. (2015). Kouchynh yak efektyvna tekhnolohiia formuvannia samoosvitnoi kompetentnosti studentiv. Problemy pidhotovky suchasnoho vchytelia, 11, 99-105.

Maksymov, V. E. (2004). Kouchynh ot A do Ya. Vozmozhno vse. Sankt-Peterburh: Rech.

Parslou, E., \& Rei, M. (2003). Kouchynh v obuchenyy. Praktycheskye metody i tekhnyky. Sankt-Peterburh: Piter.

Poberezka, H. H. (2017). Kouchynh yak pedahohichna tekhnolohiia studentotsentrychnoho navchannia u VNZ. Tekhnolohiia i tekhnika drukarstva, 4, 99-107.

Romanova, S. M. (2010). Kouchynh yak nova tekhnolohiia v profesiinii osviti. Visnyk Natsionalnoho aviatsiinoho universytetu. Ser. Pedahohika. Psykholohiia, 3, 83-86.

Uytmor, Dzh. (2005). Kouchynh vysokoi effektyvnosti. / per. s anhl. Moskva: Mezhdunarodnaia akademyia korporatyvnoho upravlenia i biznesa.

Shevchuk, S.P., \& Shevchuk, O.S. (2016). Kouchynh yak metod navchannia studentiv u konteksti reformuvannia vyshchoi osvity Ukrainy. Nauk. prats. Chornomor. derzh. u-tu im. P. Mohyly. Ser.: Pedahohika, 269(257), 62-65. 